\title{
Genetic Variation Among Isolates of the Web Blight Pathogen of Common Bean Based on PCR-RFLP of the ITS-rDNA Region
}

\author{
G. Godoy-Lutz, Instituto Dominicano de Investigaciones Agropecuarias y Forestales, Centro Sur, San Juan de la \\ Maguana, Dominican Republic; and J. R. Steadman, B. Higgins, and K. Powers, Department of Plant Pathology, \\ University of Nebraska, Lincoln 68583-0722
}

\begin{abstract}
Godoy-Lutz, G., Steadman, J. R., Higgins, B., and Powers, K. 2003. Genetic variation among isolates of the web blight pathogen of common bean based on PCR-RFLP of the ITS-rDNA region. Plant Dis. 87:766-771.

Variability of 45 isolates of Rhizoctonia solani (teleomorph Thanatephorus cucumeris) causing web blight (WB) of common bean, Phaseolus vulgaris, was examined by polymerase chain reaction-restriction fragment length polymorphism (PCR-RFLP) analysis of the internal transcribed spacer regions (ITS1 and ITS2) and the 5.8S subunit (5.8S) of the nuclear ribosomal DNA repeat (ITS-5.8S-rDNA). Isolates were collected from diseased bean leaves from Argentina, Costa Rica, Cuba, Dominican Republic, Honduras, Panama, and Puerto Rico. These WB isolates belong to AG-1 and AG-2 based on anastomosis reaction. Isolates of AG-1 that cause WB were separated into three distinct groups of RFLP patterns from enzymatic digestion of a 740-bp PCR fragment. Microsclerotia-producing isolates $(<1 \mathrm{~mm})$ were differentiated from macrosclerotia-producing isolates ( 5 to $20 \mathrm{~mm}$ ) based on PCR-RFLP patterns even though they are placed in the same AG1-1B subgroup by anastomosis reaction. WB isolates of AG-2 were separated into two distinct PCR-RFLP groups as previously reported. AG-1 macrosclerotialproducing isolates were the most virulent, whereas isolates of AG-2 were the least virulent. Genetic variability of the WB pathogen may have influenced the failure or success of management practices implemented in the past in Latin America.
\end{abstract}

Web blight (WB) of common bean (Phaseolus vulgaris L.) is caused by aerially dispersed isolates of Rhizoctonia solani Kühn (teleomorph Thanatephorus cucumeris (Frank) Donk) resulting in defoliation and pod infection which leads to mild to severe yield and seed quality losses $(13,15)$. Presently, the disease is endemic in the bean-growing regions of the Caribbean and Central America, and efforts to control WB have been ineffective and costly. The pathogen spreads by airborne basidiospores, mycelial bridges between plants, rain-splashed sclerotia, infested soil debris, and infected seeds $(13,15)$. Progress in breeding for WB resistance in common bean has been limited due to considerable variability in varietal reaction and lack of understanding of the pathogen variation and disease resistance mechanisms $(3,4)$.

Rhizoctonia solani is a species complex whose current classification is based on the

Corresponding author: J. R. Steadman

E-mail: jsteadman1@unl.edu

Accepted for publication 29 January 2003.

Publication no. D-2003-0428-01R

(C) 2003 The American Phytopathological Society occurrence of hyphal fusion with known tester isolates to establish an anastomosis group (AG). Currently, 13 AGs have been described with considerable variability existing among and within AGs (7). These variants are described as subgroups and differ in morphology, ecological habitat, survival, and virulence $(22,28)$. At least three AGs (AG-1, AG-2, and AG-4) have been associated with WB of common bean in the Americas $(6,13)$. Based on cultural characteristics and epidemiological differences, isolates of AG-1 and AG-2 of the WB pathogen appear to have intragroup variation (15).

The advent of molecular techniques has provided tools to evaluate intra- and interspecific variation of $R$. solani complex (9). Among these tools, polymerase chain reaction (PCR) and restriction fragment length polymorphism (RFLP) of the internal transcribed spacer (ITS) region of the nuclear rDNA repeat have been used to provide more understanding of the genetic diversity within the $R$. solani complex $(9,32)$. The existence of more genetically distinct subgroups within AG-1, AG-2, and AG-4 $(5,18-20,22,28)$ has also been demonstrated. Understanding the extent of diversity of the WB pathogen could explain variation in the host-pathogen interaction in terms of cultivar reaction and the limited success a decade ago of disease management recommended for web blight of common beans in the tropics. Most $R$. solani research on ecology, epidemiology, and genetics has been conducted with soilborne isolates causing root rot and stem rots in crops from temperate zones. Aerially dispersed $R$. solani groups have not received much attention even though these isolates cause severe diseases of the aboveground plant parts of economically important crops such as rice, corn, bean, sorghum, and tobacco in the tropics and subtropics (30).

To test the hypothesis that the bean WB pathogen population of Central and South America and the Caribbean was variable, the genetic diversity of WB field isolates was examined using PCR-RFLP of the internal transcribed spacer regions (ITS1 and ITS2) and the $5.8 \mathrm{~S}$ subunit $(5.8 \mathrm{~S})$ of the nuclear ribosomal DNA repeat (ITS-5.8S-rDNA) and the virulence of these isolates was determined in a detached leaf test.

\section{MATERIALS AND METHODS}

Source of isolates and maintenance. The $R$. solani isolates used in this work were obtained from leaves of commercial cultivars of $P$. vulgaris and wild beans $(P$. vulgaris aborigineus) with symptoms of web blight. These isolates have been assigned to AG-1 and AG-2 in previous studies (14). All available testers were not used to identify $R$. solani subgroups since PCRRFLP techniques can now be used. Only two testers, R-131 (AG-1-IC, formerly R43 Parmeter's collection) and R-135 (AG-2-2 from Ogoshi's collection; Fig. $1 C)$, representing the AG groups were included for comparison (Table 1). WB isolates of AG-1 were described as microsclerotia-producing with sclerotia size of $<1 \mathrm{~mm}$ in diameter, macrosclerotiaproducing with sclerotia size of 5 to 20 $\mathrm{mm}$ in diameter, and "sasakii" sclerotia type (Fig. 1B). Cultures of these isolates are maintained in repositories at the University of Nebraska, Lincoln, and the Health Sciences University of Hokkaido, Japan. All isolates were maintained on sterile sugar beet seeds at $4^{\circ} \mathrm{C}$ before transferring them to water agar (Difco Agar; 
Difco Laboratories, Detroit, MI) and potato dextrose agar (PDA; Difco Laboratories) for growth.

Isolation of mycelia DNA. Isolates were grown on a liquid V8 medium in 22$\mathrm{mm}$ deep, sterile, petri dishes at $24^{\circ} \mathrm{C}$ for a week. Mycelium was harvested by filtration, lyophilized, and ground to powder for
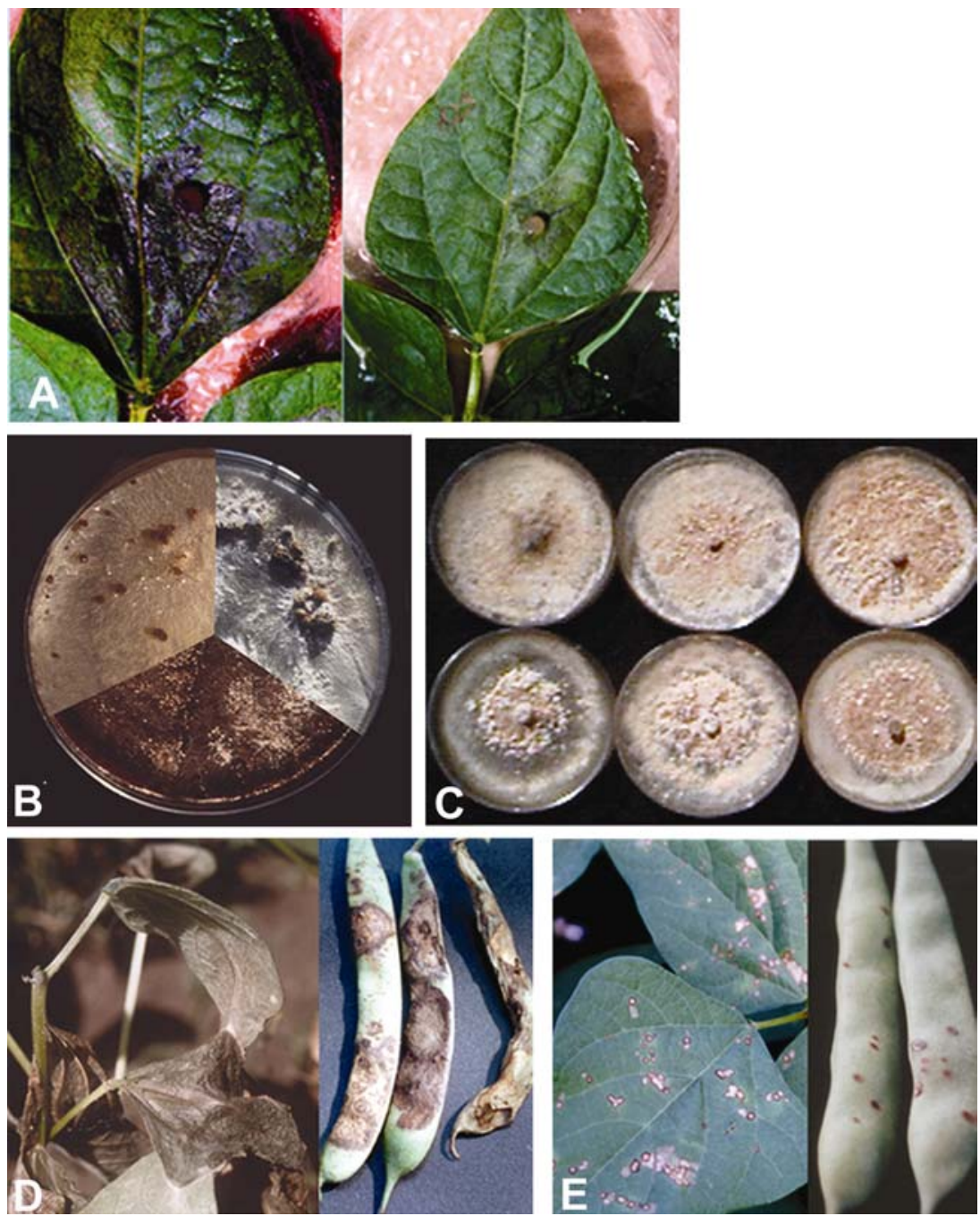

Fig. 1. Differences in Rhizoctonia solani isolates. A, lesion size on common bean cv. HT-7719 of isolates (left) P30 (macrosclerotia-producing AG-1-1B) and (right) A23 (AG-2). B, Characteristics of AG-1 isolates on potato dextrose agar (PDA) medium. Top left: sasaki isolate; top right: macrosclerotia-producing isolate; bottom: microsclerotia-producing isolate. $\mathbf{C}$, Characteristics of AG-2 isolates on PDA medium. Top row (left to right): R-135, DR-EEAL, and A-1. Bottom row: A18, A19, and A24. D, Typical web blight symptoms on leaves and pods of common bean produced by AG-1 isolates. E, Web blight symptoms on leaves and pods of common beans produced by AG-2 isolates. $\mathrm{ml}$ of $1 \mathrm{M}$ Tris Buffer (pH 7.5), and $40 \mathrm{ml}$ of $0.5 \mathrm{M}$ EDTA per liter of distilled water). After incubation, each sample was centrifuged for $10 \mathrm{~min}$ at $14,000 \mathrm{rpm}$. The supernatant was precipitated with a $6: 10$ (vol/vol) mixture of ethanol and $7 \mathrm{M}$ ammonium acetate at $-20^{\circ} \mathrm{C}$. After a $30 \mathrm{~s}$ spin, the samples were washed with $70 \%$ ethanol, reprecipitated, and then centrifuged again. The pellet was rehydrated in $200 \mu \mathrm{l}$ of TE buffer $(1 \mathrm{mM}$ Tris, $0.1 \mathrm{mM}$ EDTA), and $20 \mu \mathrm{l}$ of $100 \mu \mathrm{g} / \mathrm{liter}$ of RNase A were added. The suspension was incubated $1 \mathrm{~h}$ at $37^{\circ} \mathrm{C}$. The DNA was precipitated by adding $500 \mu \mathrm{l}$ of a 20:1 ( $\mathrm{vol} / \mathrm{vol})$ mixture of ethanol and $3 \mathrm{M}$ sodium acetate at $-20^{\circ} \mathrm{C}$. The final dilution was stored in $1 \times$ TE buffer. The concentration of each sample was estimated using an Ultrospect III spectrophotometer (Pharmacia LKB Biochrom, Cambridge, England) and diluted to give a final concentration of approximately $10 \mathrm{ng}$ of DNA per $\mu \mathrm{l}$ of buffer.

PCR and RFLP analysis of the rDNAITS region. Amplification of the nuclear rDNA region and the ITS regions including the 5.8S ribosomal DNA (ITS-5.8S-rDNA) was performed using primers ITS1 and ITS4 (34). The PCR amplification reactions were performed by adding $1 \mu \mathrm{l}$ of 500 -fold dilution of genomic DNA (10 $\mathrm{ng} / \mu \mathrm{l})$ solution to $50 \mu \mathrm{l}$ of reaction mixture of Taq buffer $(500 \mathrm{mM} \mathrm{KCL}, 100 \mathrm{mM}$ Tris- $\mathrm{HCl}, \mathrm{pH} 8.3,1.5 \mathrm{mM} \mathrm{MgCl}_{2}$, and $0.001 \%$ gelatin) and $100 \mathrm{mM}$ dNTP, 20 $\mathrm{mM}$ primers ITS1/ITS4 and two units of Taq polymerase (U/ml) (Promega, Madison, WI). Amplification was performed in a GeneE Thermal Cycler with heated lid (Techne Inc., Princeton, NJ) programmed for 40 cycles with the following temperature profile: $1 \mathrm{~min}$ at $94^{\circ} \mathrm{C} ; 1 \mathrm{~min}$ at $53^{\circ} \mathrm{C}$; and $105 \mathrm{~s}$ at $72^{\circ} \mathrm{C}$. Cycling ended with a final extension step at $72^{\circ} \mathrm{C}$ for $5 \mathrm{~min}$. Amplification products were separated in a 1\% Agarose Low EEO (Fisher Scientific Co, Pittsburg, PA) gel in Tris-borate EDTA buffer at $105 \mathrm{~V}$ for $1 \mathrm{~h}$ and visualized by ethidium bromide staining on a UV transilluminator. Restriction endonuclease digestion of DNA amplification of each isolate was performed with MspI, HaeIII, AluI, MboI, and TaqI according to Kanamatsu and Naito (18) and Liu and Sinclair (20). $B s r$ DI was included for its usefulness in

Table 1. Isolates of Rhizoctonia solani used in this study

\begin{tabular}{lll}
\hline Isolate code & \multicolumn{1}{c}{ Host } & \multicolumn{1}{c}{ Origin } \\
\hline A1, A4, A6-8, A11 & Phaseolus vulgaris aborigineus & Jujui Province, Argentina \\
A18-21, A23, A24, A27, A28 & P. vulgaris aborigineus & Salta Province, Argentina \\
H-32-34, H38, H39 & P. vulgaris cv. Dorado & El Barro, Honduras \\
H-45, H46 & P. vulgaris cv. Dorado & Lavanderos, Honduras \\
CR10, CR11 & P. vulgaris cv. MUS 181 & Guatuso, Costa Rica \\
DR-BV1, DR-BV18, 22, 33, 42, 98, DR-EEAL, DR-J2, DR-HPD & P. vulgaris cv. PC-50 & San Juan Valley, Dominican Republic \\
Cuba 2 & P. vulgaris unknown & La Habana, Cuba \\
P6, P10, P30, P35, P40, P41 & P. vulgaris cv.Barriles & Caizan, Panama \\
PR5, PR11, PR25, PR34, PR45, PR50 & P. vulgaris cv. Arroyo Loro & La Isabela, Puerto Rico \\
R131 & $\ldots$ & Formerly R43 Parmeter's collection (AG-1-IC) \\
R135 & $\ldots$ & Ogoshi's collection (AG-2-2) \\
\hline
\end{tabular}


detecting polymorphisms in other foliar pathogens (24).

Virulence test. Seventeen $R$. solani isolates representing the range of restriction site polymorphisms of the amplified ITS region were tested for virulence. Mycelial disks $(20 \mathrm{~mm})$ from 2-day-old $R$. solani cultures grown on PDA were placed on the top surface of a detached second trifoliolate of the bean cv. HT 7719 (WB field tolerant, Middle American origin), placed in an aluminum roasting pan, covered with plastic film which maintains the chamber (pan) at constant high humidity. Leaf lesion area was determined by hand measurement after $48 \mathrm{~h}$ at $22^{\circ} \mathrm{C}$. This method has been used to screen soybeans, beans, and canola against Sclerotinia sclerotiorum (29), a necotrophic pathogen like $R$. solani. The method is currently used for web blight resistance screening (J. Beaver, personal communication). The experiment was a randomized complete block design with three replications and was repeated twice. Analysis of variance and mean separation were performed using the MSTAT-C v 2.11 program (Department of Soils and Crops, Michigan State University, East Lansing).

\section{RESULTS}

PCR amplification and RFLP of the rDNA-ITS region. Amplification of the ITS-5.8S-rDNA region of the nuclear rDNA repeat of $47 R$. solani isolates yielded DNA fragments estimated at 740 bp, except tester R-131, which had a 700bp length. Restriction enzyme digestions of the amplified DNA of all isolates with AluI, BsrDI, EcoRI, HaeIII, MboI, MspI and $T a q \mathrm{I}$ restriction enzymes resulted in six distinct patterns (Tables 2 and 3 ).

AG-1 WB isolates were separated into three distinct RFLP patterns (I to III) from digestions with HaeIII, BsrDI, AluI, MboI and TaqI (Table 2). The separation of isolates based on these patterns was in agreement with the subgroups separated on morphological and cultural differences. The tester isolate, R-131, gave a pattern that was different from the other AG-1 isolates. The RFLP pattern I was represented by isolate CUBA 2. Restriction enzyme digestions with $A l u \mathrm{I}$ generated two products consistent with a single restriction site. HaeIII and TaqI restriction enzyme digestions generated three products consistent with two restriction sites. $\mathrm{MboI}$ digestions revealed five restriction sites in the
ITS-5.8S-rDNA region. The restriction enzyme $B s r$ DI yielded only a single fragment of the same size as the amplified region. The restriction enzyme fragments from HaeIII, AluI, TaqI, and MboI digestions closely resembled those reported by Schneider et al (26) and Liu and Sinclair (20) for AG-1-IA isolates.

The RFLP pattern II was generated by the AG-1-IB microsclerotia-producing isolates of the WB pathogen from the Dominican Republic and Honduras. The amplified ITS-5.8S-rDNA region of these isolates had two restriction sites for HaeIII, three for $A l u \mathrm{I}$ (Fig. 2A) and $T a q \mathrm{I}$, and four for $M b o I$. The restriction enzyme BsrDI yielded only a single fragment of the same size as the amplified region (Fig. 2B). Fragments generated by TaqI digestions with these isolates were different in size and number from other AG-1-I B isolates from soil and sugar beet and examined by Schneider et al. (26) and Liu and Sinclair (20).

The RFLP pattern III was generated by the macrosclerotia-producing isolates of AG-1-IB from Puerto Rico and Panama. The ITS-5.8S-rDNA region of these isolates had two restriction sites for HaeIII, AluI (Fig. 2A), and TaqI and four sites for

Table 2. Estimated restriction fragment length of the ITS-rDNA region for Rhizoctonia solani AG-1 isolates of the web blight pathogen of common beans

\begin{tabular}{|c|c|c|c|c|c|c|c|}
\hline \multirow[b]{2}{*}{ Anastomosis group/subgroups } & \multicolumn{5}{|c|}{$\begin{array}{l}\text { Fragment length in base pair } \\
\text { using restriction enzymes }\end{array}$} & \multirow{2}{*}{$\begin{array}{l}\text { ITS-RFLP } \\
\text { pattern }^{y}\end{array}$} & \multirow[b]{2}{*}{ Isolates } \\
\hline & HaeIII & BsrDI & Alu I & $\operatorname{Taq} \mathbf{I}$ & MboI & & \\
\hline AG-1-IA & $\begin{array}{r}550 \\
125 \\
65\end{array}$ & 740 & $\begin{array}{l}520 \\
220\end{array}$ & $\begin{array}{r}380 \\
300 \\
60\end{array}$ & $\begin{array}{r}250 \\
210 \\
140 \\
65 \\
50 \\
25^{\mathrm{z}}\end{array}$ & I & Cuba 2 \\
\hline AG-1-IB (microsclerotia-producing) & $\begin{array}{r}550 \\
125 \\
65\end{array}$ & 740 & $\begin{array}{r}340 \\
200 \\
120 \\
80\end{array}$ & $\begin{array}{r}360 \\
260 \\
65 \\
55\end{array}$ & $\begin{array}{c}280 \\
250 \\
140 \\
55 \\
15^{z}\end{array}$ & II & $\begin{array}{l}\text { DR-BV1, DR-BV8, DR-BV22, DR-BV33, DR-BV42, } \\
\text { DR-BV98, H32, H33, H34, H38, H39 }\end{array}$ \\
\hline AG-1-IB (macrosclerotia-producing) & $\begin{array}{r}550 \\
125 \\
65\end{array}$ & $\begin{array}{l}575 \\
165\end{array}$ & $\begin{array}{r}500 \\
200 \\
40\end{array}$ & $\begin{array}{r}380 \\
300 \\
60\end{array}$ & $\begin{array}{r}260 \\
250 \\
140 \\
55 \\
35\end{array}$ & III & $\begin{array}{l}\text { PR5, PR11, PR25, PR34, PR45, PR50, P6, P10, P30, } \\
\text { P35, P40, P41 }\end{array}$ \\
\hline AG-1-IC & $\begin{array}{r}400 \\
125 \\
100 \\
75\end{array}$ & 700 & $\begin{array}{l}500 \\
200\end{array}$ & $\begin{array}{r}360 \\
280 \\
60\end{array}$ & $\begin{array}{r}250 \\
240 \\
135 \\
55\end{array}$ & IV & $\mathrm{R}-131$ \\
\hline
\end{tabular}

y ITS = internal transcribed spacer region. RFLP $=$ restriction fragment length polymorphism.

${ }^{\mathrm{z}}$ Fragments $25 \mathrm{bp}$ or smaller in length not visualized on RFLP gel were inferred from nucleotide base pair length.

Table 3. Estimated restriction fragment length of the ITS-rDNA region of Rhizoctonia solani AG-2 isolates of the web blight pathogen of common beans

\begin{tabular}{|c|c|c|c|c|c|c|}
\hline \multirow[b]{2}{*}{ Anastomosis group/subgroup } & \multicolumn{4}{|c|}{$\begin{array}{l}\text { Fragment length in base pair } \\
\text { using restriction enzymes }\end{array}$} & \multirow{2}{*}{$\begin{array}{l}\text { ITS RFLP } \\
\text { pattern }^{\mathbf{z}}\end{array}$} & \multirow[b]{2}{*}{ Isolates } \\
\hline & EcoRI & MspI & Hae III & $\operatorname{Taq} \mathbf{I}$ & & \\
\hline AG-2-2 & $\begin{array}{l}390 \\
350\end{array}$ & $\begin{array}{l}590 \\
150\end{array}$ & $\begin{array}{l}600 \\
140\end{array}$ & $\begin{array}{r}360 \\
310 \\
70\end{array}$ & $\mathrm{~V}$ & $\begin{array}{l}\text { R-135, DR-EEAL, DR-J2, DR-HPD, CR10, CR11, } \\
\text { A1, A4, A6, A7, A11, H-45, H46 }\end{array}$ \\
\hline AG-2 unknown & $\begin{array}{l}390 \\
350\end{array}$ & $\begin{array}{l}590 \\
150\end{array}$ & $\begin{array}{l}400 \\
190 \\
140\end{array}$ & $\begin{array}{r}360 \\
310 \\
70\end{array}$ & VI & $\mathrm{A} 8, \mathrm{~A} 18, \mathrm{~A} 19, \mathrm{~A} 20, \mathrm{~A} 21, \mathrm{~A} 23, \mathrm{~A} 24, \mathrm{~A} 27, \mathrm{~A} 28$ \\
\hline
\end{tabular}

${ }^{\mathrm{z}}$ ITS = Internal transcribed spacer region. RFLP = restriction fragment length polymorphism. 
MboI. Digestions with BsrDI yielded two fragments of 575 and 165 bp (Fig. 2B). Other researchers indicated that $A l u \mathrm{I}$ and MboI digestions of the ITS-5.8S-rDNA region showed two and three restriction sites, respectively, for AG-1-I B isolates $(20,26)$.

The RFLP pattern IV was represented by tester isolate R-131 where restriction enzymes AluI, TaqI, HaeIII, and MboI had one, two, three, and four restriction sites, respectively, in the amplified ITS-5.8SrDNA region. Restriction enzyme BsrDI yielded only a fragment of the same size as the amplified region (Fig. 2B). These results are in agreement with other reports for AG-1-IC isolates $(20,26)$.

AG-2 WB isolates produced RFLP patterns $\mathrm{V}$ and $\mathrm{VI}$ from restriction enzyme digestion of the amplified ITS-5.8S-rDNA region (Table 3). These two patterns represented WB field isolates from Costa Rica, Dominican Republic, and Honduras and isolates causing WB in wild beans in the Andean mountain rainforests of Argentina. RFLP pattern $\mathrm{V}$ had one restriction site for EcoRI, MspI, HaeIII, and two for TaqI. The isolates fit the RFLP pattern previously reported for cultural types AG-2-2 IV from sugar beets $(16,18)$. The RFLP pattern VI showed similar results with EcoRI, MspI, and TaqI but not with HaeIII, which showed two restriction sites (Fig. 3) (16). A Japanese AG-2-1 isolate from peas and isolates of a newly described subgroup AG-2t, associated with diseases of crucifers and tulips in the Netherlands, have two restriction sites in the ITS-5.8S-rDNA region (26). However, they can be clearly differentiated from the AG-2 isolates that cause WB on wild beans by fragment lengths in the RFLP profile.

Virulence. All of the isolates caused lesions on the second trifoliolates of bean plants (Table 4). Isolates typed to AG-1 developed extensive water-soaked and necrotic lesions within 2 days after inoculation and were collectively more virulent than those of AG-2 (Fig. 1A). Macrosclerotia-producing isolates were more virulent than the microsclerotia-producing isolates of the AG-1-IB subgroup on the bean genotype tested. Visible lesions produced by AG- 2 isolates developed a day later than those produced by AG-1, and these AG-2 caused-lesions were not accompanied by water soaking but did produce yellowing and further necrosis. Isolate A28, collected from wild beans in Argentina, was significantly more virulent than the other AG-2 isolates.

\section{DISCUSSION}

Web blight of common bean is caused by at least five genetically distinct $R$. solani subgroups based on the polymorphism of restriction enzyme digestions of the ITS-5.8S-rDNA region of 45 isolates. The WB isolates were obtained from beangrowing regions in seven countries in Latin America and the Caribbean and those classified as AG-1 fell into three distinct ITSRFLP patterns while those classified as AG-2 showed two patterns. In our study, isolates from AG-1 or AG-2 that shared similarities in cultural characteristics, sclerotia, and virulence, also displayed similar RFLP patterns regardless of geographical or varietal host origin. Traditionally, AG-1 isolates of $R$. solani have been subdivided into AG-1-IA, AG-1-IB, and AG-1-IC according to host origin, symptoms, sclerotia form, cultural characteristics, and DNA sequence homology $(22,28)$. The AG-1-IA (rice sheath blight) isolates are known for their "sasakii "(primitive rind) sclerotia type and cause sheath blight of rice, sorghum, and corn and aerial blights of soybean $(17,28,35)$. The AG-1-IB is the web blight form of $R$. solani AG-1 and affects various row crops and ornamentals in tropical and subtropical regions (Fig. 1D). The AG-1-IC (damping-off) isolates affect primarily seedlings of various crops $(22,28)$. Only one isolate from a black seeded bean variety grown in northern Cuba was separated by RFLP banding pattern and cultural characteristics into subgroup AG-1-IA. The remaining isolates were assigned to AG-1-IB based on molecular differentiation of AG-1 isolates by Liu and Sinclair (20).

The ITS-RFLP method also was able to discriminate isolates that produce micro- or
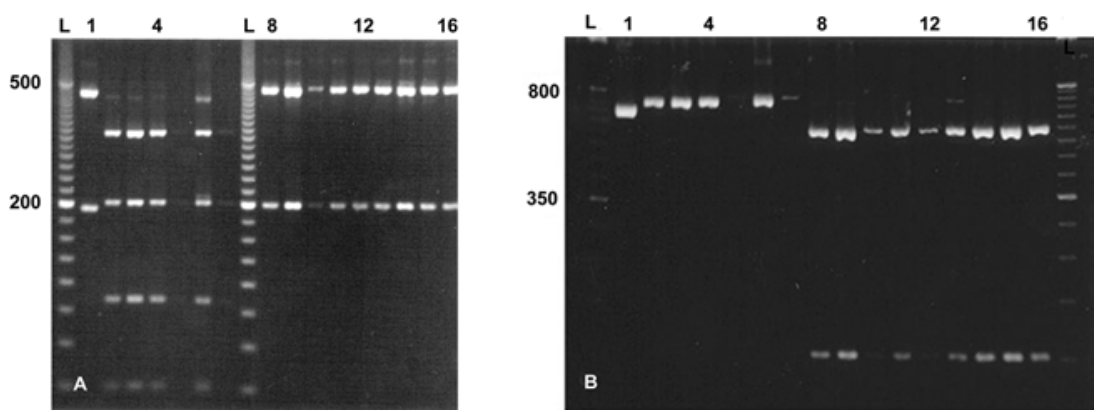

Fig. 2. Restriction digestion patterns of the nuclear ribosomal DNA-internal transcribed spacer region between primers ITS1 and ITS4 in Rhizoctonia solani AG-1 isolates using $A l u \mathrm{I}$ and $B s r \mathrm{DI}$ endonucleases. A, L: 20-bp ladder (AluI) and B, L: 50-bp ladder (BsrDI); 1: R131 (AG-1-IC tester); 2: BV1; 3: BV22; 4: BV36; 5: H32; 6: H33; 7: H34; 8: PR5; 9: PR11; 10: PR25; 11: PR34; 12: PR45; 13: PR50; 14: P6; 15: P10; 16: P30. macrosclerotia in culture, as separate genetic entities. Both had been previously assigned to AG-1-IB based on subgroup description even though cultural and morphological characteristics warranted their separation (23). Other researchers have reported that isolates causing web blight of common bean and aerial blight of soybean produce micro- and macrosclerotia simultaneously on host tissue $(2,31,33)$. Our isolates however, showed only one distinctive sclerotia type on PDA and only microsclerotia-producing isolates have developed sclerotia under field conditions (unpublished data). These microsclerotia can function as airborne propagules causing secondary infections and facilitating pathogen spread and inoculum build up (35).

Microsclerotia- and macrosclerotiaproducing isolate banding patterns consistently showed evidence of genetic homogeneity within both subgroups. We did not

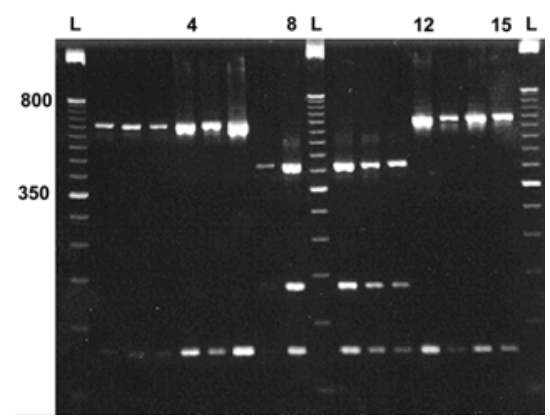

Fig. 3. Restriction digestion patterns of the nuclear ribosomal DNA-internal transcribed spacer region between primers ITS1 and ITS4 in Rhizoctonia solani AG-2 isolates using HaeIII endonuclease. L: 50-bp ladder; 1: R135 (AG2-2 tester); 2: A1; 3: A4; 4: A6; 5: A7; 6: A11; 7: A18; 8: A20; 9: A21; 10: A23; 11: A28; 12: DR-J2; 13: DR-HPD; 14: CR-10; 15: CR-11.

Table 4. Lesion area produced on trifoliolate leaves of common bean cv. HT7719 in humid chambers by Rhizoctonia solani that causes web blight

\begin{tabular}{lc}
\hline Isolate & Lesion area $\left(\mathbf{c m}^{2}\right)$ \\
\hline PR5 & $5.12 \mathrm{a}^{\mathrm{z}}$ \\
P30 & $3.89 \mathrm{~b}$ \\
P6 & $3.85 \mathrm{~b}$ \\
Cuba 2 & $3.20 \mathrm{c}$ \\
R131 & $3.06 \mathrm{c}$ \\
A28 & $3.02 \mathrm{~cd}$ \\
H32 & $3.01 \mathrm{~cd}$ \\
DR-BV22 & $2.93 \mathrm{cde}$ \\
DR-BV1 & $2.57 \mathrm{cde}$ \\
A27 & $1.81 \mathrm{defg}$ \\
DR-EEAL & $1.73 \mathrm{fg}$ \\
A23 & $1.43 \mathrm{fg}$ \\
A4 & $1.33 \mathrm{~g}$ \\
H46 & $1.04 \mathrm{~g}$ \\
DR-J2 & $0.89 \mathrm{~g}$ \\
H45 & $0.87 \mathrm{~g}$ \\
R135 & $0.77 \mathrm{~g}$ \\
LSD $(P=0.05)$ & 1.23 \\
\hline
\end{tabular}

${ }^{\mathrm{z}}$ Values in column followed by the same letter are not significantly different at $P=0.05$ according to Fisher's least significant difference test transformed data. 
detect any heterogeneity or random variation in ITS-RFLP profiles from any isolate as previously reported for isolates within subgroups of AG-1 and AG-2 (16,26). Liu and Sinclair (20) characterized isolates that did not conform to AG-1 subgroups IA, IB, or IC as ID, IE, and IF using the rDNAITS and isozyme profiles. Our isolates did not fully conform to these profiles. The ITS-RFLP profiles suggest a further separation of AG-1-IB isolates of the WB pathogen of common beans that produce microsclerotia from those that produce macrosclerotia. Work is in progress to sequence the amplified rDNA-ITS region to obtain more genetic information on these isolates. Web blight symptoms on common bean also have been associated with undescribed subgroups of AG-2 $(6,11)$. However, these symptoms more closely fit the description of foliar blights than typical web blights since AG-2 isolates do not develop "cobweb-like mycelia" on foliage. Instead, infection-causing basidiospores are produced and disseminated from hymenia borne underneath infected trifoliolate leaves. Small $(1 \mathrm{~mm})$ circular necrotic lesions are observed commonly in the upper plant canopy (Fig. 1E). When conditions are humid and warm, these lesions develop secondary, irregularly shaped, water-soaked lesions that expand and coalesce giving a "scalded" appearance to infected plants. The basidial stage of the WB pathogen has been reported in bean fields in Costa Rica, Colombia, and Dominican Republic $(6,10,14)$. Aerial isolates of $R$. solani AG-2 incite foliar blights of economically important crops such as sugar beet and soybean $(21,22)$ in Japan and the United States.

AG-2 isolates can be identified according to hyphal fusion frequency, thiamine requirements, and cultural characteristics (28). However, these are time consuming and require considerable expertise. Molecular techniques, such as PCR-RFLP and rDNA sequence analysis, have facilitated the identification of cultural and ecological types within subgroups. Currently, there are three subgroups: AG-2-1, AG-2-2 (with three cultural types IIIB, IV, and LP), and AG-2-3. A newly defined cultural type AG-2t also has been differentiated on the basis of sequences of the ITS- rDNA region (26).

Interestingly, our isolates from bean fields in Costa Rica, Dominican Republic, and Honduras as well as some rainforest isolates from argentinian wild bean were assigned to AG-2-2 IV. Members of this cultural type have been previously described as pathogens to Chenopodiaceae hosts such as sugar and table beets $(22,28)$. This indicates that host range and geographical location are becoming less important in delimiting subgroups of $R$. solani. The finding that ITS-RFLP patterns of wild bean isolates differ from those of previously described subgroups placed into the AG-2 category demonstrates the need to obtain more information on indigenous plant pathogens at the center of host origin.

Subgroups of $R$. solani AG-2 are characterized as genetically stable independent populations and exist in very broad geographical regions (19). Regional germ plasm exchange of unknowingly contaminated seed of land races or wild beans could be one important avenue for widespread distribution of undescribed subgroups of $R$. solani.

Variation in virulence also was recorded among subgroups of the WB pathogen. AG-1 macrosclerotia-producing isolates were the most virulent, whereas isolates of AG-2 were the least virulent. Similar results have been reported with Puerto Rico WB-isolates in greenhouse virulence tests (23) and in field trials of the Latin American and Caribbean Nurseries where virulence patterns varied among countries of origin and bean genotypes (3).

The observation of a wide range of virulence on HT 7719 has important implications for breeding for WB resistance. This bean line was developed specifically for web blight resistance in 1986 by the Centro Internacional de Agricultura Tropical (CIAT) and has been widely used as a parent in breeding programs in Latin America (8). Over time, development and spread of virulent fungal pathotypes or new subgroups of $R$. solani could have overcome resistance in HT 7719.

In $R$. solani, genetic variation in populations can be due to sexual recombination, heterokariosis fusion, and mutation (1). Genetic analysis of populations of $R$. solani AG-1-IA, causal agent of sheath blight of rice in Texas, revealed that novel genotypes were generated by sexual recombination and increased by asexual reproduction to high frequency (25). Similar mechanisms could allow AG-1 isolates of the WB pathogen to develop new virulent types since these isolates can develop the sexual stage under favorable field conditions $(2,12,33,36)$. Spatial and temporal distribution of $R$. solani pathotypes can occur via asymptomatic infected seed (15) and other agronomic practices that contribute to dispersal of asexual propagules such as mycelia and sclerotia.

Knowledge about the genetic composition of aerial $R$. solani populations have influenced management decisions in other crops such as soybean and rice where crop rotation, intercropping, breeding, and cultural and chemical control have been modified and/or improved based on proper identification of the predominant subgroup (17). For common bean, the finding of different subgroups associated with WB will influence management practices implemented for this disease in the tropics.

\section{ACKNOWLEDGMENTS}

A contribution of the University of Nebraska Agricultural Research Division, Lincoln, NE
68583 Journal Series No. 13603. We acknowledge financial support for this research from the Bean/Cowpea CRSP (USAID Contract No. DAN1310-G-SS-6608-00).

\section{LITERATURE CITED}

1. Adams, G. C. 1996. Genetics of Rhizoctonia species. Pages 101-106 in: Rhizoctonia species: Taxonomy, Molecular Biology, Ecology, Pathology and Disease Control. B. Sneh, S. Jabaji-Hare, S. Neate, and G. Dijst, eds. Kluwer Academic Publishers, Dorchecht, the Netherlands.

2. Atkins, J. G. and Lewis, W. D. 1954. Rhizoctonia aerial blight of soybeans in Louisiana. Phytopathology 44:215-218.

3. Beaver, J. S., and Steadman, J. R. 1999. Adelantos en el mejoramiento de frijol andino caribeno. Agron. Mesoamericana 10:77-82.

4. Beebe, S. E., and Pastor Corrales, M. A. 1991 Breeding for disease resistance. Pages 561617 in: Common Beans Research for Crop Improvement. A. van Schoonhoven and O. Voysest, eds. CAB International, Wallingford, U.K. and CIAT, Cali, Colombia.

5. Boysen, M., Borja, M., del Moral, C., Salazar, O., Rubio, V. 1996. Identification at strain level of Rhizoctonia solani AG-4 isolates by direct sequence asymmetric PCR products of the ITS regions. Curr. Genet. 29:174-181.

6. Cardenas, M. R. 1989. Web blight of beans (Phaseolus vulgaris L.) incited by Thanatephorus cucumeris (Frank) Donk in Colombia. Ph.D thesis. Cornell University, Ithaca, N.Y.

7. Carling, D. 1996. Grouping in Rhizoctonia solani by hyphal anastomosis reaction. Pages 37-47 in: Rhizoctonia species: Taxonomy, Molecular Biology, Ecology, Pathology and Disease Control. B. Sneh, S. Jabaji-Hare, S. Neate, and G. Dijst eds. Kluwer Academic Publishers. Dorchecht the Netherlands.

8. CIAT (Centro Internacional de Agricultura Tropical) 1987. Bean Progr. Annu. Rep. 1986. Cali, Colombia.

9. Cubeta, M. A., and Vilgalys, R. 1997. Population biology of the Rhizoctonia solani complex. Phytopathology 87:480-484.

10. Echandi, E. 1965. Basidiospore infection by Pellicularia filamentosa (= Corticium microsclerotia), the incitant of web blight of common bean. Phytopathology 55:698-699.

11. Galindo, J. J., Abawi, G. S., Thurston, H. D., and Galvez, G. 1982. Characterization of Thanatephorus cucumeris isolates causing web blight of beans in Costa Rica. Turrialba 32:447-455.

12. Galindo, J. J., Abawi, G. S., Thurston, H. D., and Galvez, G .1983. Effect of mulching on web blight of beans in Costa Rica. Phytopathology 73:610-615.

13. Galvez, G. E., Mora, B., and Pastor Corrales, M. A. 1989. Web blight. Pages 195-259 in: Bean Production Problems in the Tropics. H. F. Schwartz and M. A. Pastor Corrales, eds. CIAT, Cali, Colombia.

14. Godoy-Lutz, G., Arias, J., Saladin, F., Steadman, J. R., and Carling, D. E. 1996. Characterization of isolates of $R$. solani that cause web blight of common beans in Central America and the Caribbean with implications for disease management. Annu. Rep. Bean Improv. Coop. 39:154-155.

15. Godoy-Lutz, G., Arias, J., Steadman J. R., and Eskridge, K. M. 1996. Role of natural seed infection by the web blight pathogen in common beans, seed damage, seedling emergence and early disease development. Plant Dis 80:887-890.

16. Hyakumachi, M., Mushida, T., Ogiso, Y., Toda, T., Kageyama, K. and Tsuge, T. 1998. Characterization of a new cultural type LP of Rhizoctonia solani AG-2-2 isolated from 
warm-season turfgrasses, and its genetic differentiation from other cultural types. Plant Pathol. 47:1-9.

17. Jones, R. K., and Belmar, S. B. 1989. Characterization and pathogenicity of Rhizoctonia spp. isolated from rice, soybean and other crops grown in rotation with rice in Texas. Plant Dis. 73:1004-1010.

18. Kanematsu, S., and Naito, S. 1995. Genetic characterization of Rhizoctonia solani AG-2-3 by analyzing restriction fragment length polymorphism of nuclear ribosomal DNA internal transcribed spacers. Ann. Phytopathol. Soc. Jpn. 61:18-21.

19. Liu, Z. L, and Sinclair, J. B. 1992. Genetic diversity of Rhizoctonia solani anastomosis group 2. Phytopathology 82:778-787.

20. Liu, Z. L, and Sinclair, J. B. 1993. Differentiation of intraspecific groups within anastomosis group 1 of Rhizoctonia solani using ribosomal DNA internal transcribed spacer and isozyme comparisons. Can. J. Plant Pathol. 15:272-280.

21. Naito, S., Nakajima, T., and Ohtou, Y. 1993. Anastomosis subgroup and characteristics of isolates from diseased leaves of soybeans caused by basidiospores of Rhizoctonia solani AG-2. Ann. Phytopath. Soc. Jpn. 59:284-222.

22. Ogoshi, A.1987. Ecology and pathogenicity of anastomosis and intraspecific groups of Rhizoctonia solani Kühn. Annu. Rev Phyto- pathol. 25:125-143.

23. Polanco, T., Rodriguez, R., y Beaver, J. S. 1996. Variabilidad entre aislados de Rhizoctonia solani en Puerto Rico. J. Agric. Univ. Puerto Rico 80:195-197.

24. Powers, K. S., Higgins, R. S., Steadman, J. R., and Powers, T. O. 1999. Ribosomal DNA restriction site variation and small subunit (SSU) rDNA group 1 introns in Sclerotinia species. (Abstr.) Phytopathology 89:S107.

25. Rosewich, U. L., Pettway, R. E., McDonald, B. A., and Kistler, H. C. 1999. High levels of gene flow and heterozygote excess characterize Rhizoctonia solani AG-1-IA (Thanatephorus cucumeris) from Texas. Fungal Genet. Biol. 28:148-159.

26. Schneider, J. H. M., Salazar, O., Rubio, V., and Keijer, J. 1997. Identification of Rhizoctonia solani associated with field grown tulips using ITS $r$ DNA polymorphism and pectic zymograms. Eur. J. Plant Pathol. 103:607622.

27. Skroch, P., and Nienhuis, J. 1995. Impact of scoring error and reproducibility of RAPD data on RAPD based estimates of genetic distance. Theor. Appl. Genet. 91:1086-1090.

28. Sneh, B., Burpee, L., and Ogoshi, A. 1991.Identification of Rhizoctonia species. The American Phytopathological Society, St. Paul, MN.

29. Steadman, J. R., Powers, K., and Higgins, B.
1997. Screening common bean for white mold resistance using detached leaves. Annu. Rep. Bean Improv. Coop. 40:140-141.

30. Sumner, D. 2001. Rhizoctonia diseases. Pages 857-858 In: Encyclopedia of Plant Pathology Vol. II. O. C. Maloy and T. D. Murray, eds. John Wiley \& Sons, Inc. New York.

31. Verma, H. S., and Thapliyal, P. N. 1976 Rhizoctonia aerial blight of soybeans. Indian Phytopathol. 29:389-391.

32. Vilgalys, R., and Gonzalez, D. 1990. Ribosomal DNA restriction fragment length polymorphism in Rhizoctonia solani. Phytopathology 80:151-158.

33. Weber, G. F. 1939. Web blight, a disease of beans caused by Corticium microsclerotia. Phytopathology 27:559-575.

34. White, T. J., Bruns, T. D., Lee, S., and Taylor, J 1990. Amplification and direct sequencing of fungal ribosomal RNA for phylogenetics. Pages 315-322 In: PCR Protocols: A Guide to Methods and Applications. M. A Innis, D. H Gelfland, J. J. Sninsky, and T. J. White, eds. Academic Press, San Diego.

35. Yang X. B., Berggren, G. T., and Snow, J. P. 1990. Types of Rhizoctonia foliar blight on soybean in Louisiana. Plant Dis. 74:501-504.

36. Yang X. B., Snow J. P., and Berggren, G. T 1988. Survey of reproductive forms of Rhizoctonia solani on soybeans in Louisiana. Plant Dis. 72:644. 